\title{
PRIMARY SCHOOL MATHEMATICS TEACHER REFLECTION THROUGH A MODELLING-BASED PROFESSIONAL DEVELOPMENT PROGRAMME
}

\author{
Piera Biccard \\ University of South Africa, Department of Curriculum and Instructional Studies, \\ College of Education \\ biccap@unisa.ac.za
}

\section{ABSTRACT}

This article contributes to the discussion on mathematics teacher reflection. Reflection was included in a study of the didactisation practices of primary school mathematics teachers as one of nine didactisation practices. The study involved five volunteer primary school mathematics teachers. A qualitative design-research approach was designed which employed model-eliciting tasks to create new experiences for teachers. This article reports on the nature and development of mathematics teacher reflection. Teacher reflection was gauged at various times during the programme through written responses to open-ended reflective questionnaires. Teachers were involved in three types of sessions for a period of one year: 1) modelling sessions whereby they collaboratively solved a mathematical modelling task; 2) observing primary school students/learners solve the same problems and 3) sessions discussing traditional and problem-centred teaching and learning. It was found that modelling tasks provided reflective platforms and a window to teacher resources, orientations and goals. It is recommended that further research into mathematics teacher reflection be conducted where teachers specifically implement modelling in their own classrooms.

Keywords: mathematics teaching, modelling tasks, primary school teacher reflection, teacher development

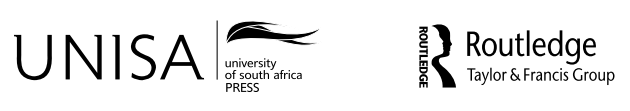

Africa Education Review

http://www.tandfonline.com/raer20
DOI: http://dx.doi.org/

ISSN 1753-5921 (Online), ISSN 1814-6627 (Print)

(C) Unisa Press 2017 


\section{REFLECTION IN MATHEMATICS TEACHER DEVELOPMENT}

Teacher reflection is an ill-defined, multi-dimensional and complex concept that needs further study internationally (Bean and Stevens, 2002; Beauchamp, 2015; Hatton and Smith, 1995; Russell, 2005) and in South Africa (Posthuma, 2012). Schön (1987, 26) highlighted areas of the reflective thinking of professionals. His distinctions of framing and reframing stem from problematic situations that can lead professionals to recognise new ways of thinking. He emphasised that these problematic situations derive from "uncertainty, uniqueness and value conflict" (p. 6). This echoes Dewey's $(1910,9)$ earlier work that sets out reflective sub-processes in terms of perplexity and the investigation of beliefs underpinning the perplexity. Reframing is about seeing pedagogical experiences differently. Korkko, Kyro, Ammala and Turunen (2016), who are working with pre-service teachers, proposed that when new knowledge or insight (gained through reflective reframing) is integrated into current knowledge, new teaching perspectives should be developed. When engaging in new or perplexing experiences that catalyse reflection, teachers may be able to re-orientate or transform their teaching perspectives. Many countries are concerned about improving mathematics teaching. Zaslavsky and Leiken (2004) affirmed that reflection is a key issue when developing mathematics teachers.

In the field of mathematics education, Linares and Krainer (2006) identified (within PME -Psychology of Mathematics Education research), that reflection promotes teacher change and development. From a modelling perspective, Brady, Lesh and Sevis $(2015,63)$ stated that programmes with "in situ reflections on practice" are favoured while Maa $\beta$ and Gurlitt $(2011,631)$ found that where reflection was embedded into professional development programmes, it resulted in teachers changing. This article adds to the discussion on reflection of mathematics teachers by discussing the results of a development programme in which modelling tasks were employed as critical situations to catalyse reflective thinking. These situations, as well as the reflections on the teacher and learner/student modelling sessions were brought into focus. It was found that the overall pedagogy of the teachers also improved (see Biccard, 2013). This supports the stance of Zeichner and Liston (1996, xvii) that reflection enables teachers to become more skilful and competent.

Research shows that mathematics teachers are not always aware of reflection in their thinking (Ticha and Hospesova, 2006). Stein and Smith (1998) found that focusing on mathematical tasks can assist teachers in a systematic and deliberate reflection process. This study used modelling tasks as problematic experiences on which the teachers had to reflect deliberately and systematically in order to create an environment to reflect on their pedagogy. Artzt, Armour-Thomas, Curcio and Gurl $(2015,5)$ consider mathematics teaching as more than what teachers do in the classroom; it extends to teachers' reflections on their pedagogy. In order to facilitate this thinking, Bean and 
Stevens (2002) suggest that various opportunities in many formats should be available for teacher reflection. The professional development programme in this study provided a three-tiered intervention with reflection opportunities across all three levels. Teachers reflected on 1) the modelling tasks they solved themselves; 2) their experiences of observing students/learners solve the same tasks and; 3) their own classroom practices. This article considers how modelling tasks impact on the reflective ideas of mathematics teachers.

Teacher decisions and actions are a result of interconnected resources, orientations and goals (Schoenfeld 2011, 8; Artzt et al. 2015, 5). A teacher's resources (which include teacher knowledge), orientations or goals must change to prompt a change in the actions of teachers. The author anticipated that modelling tasks (as problematic situations) would create a reflective platform with a view to teacher resources, orientations and goals. Bansilal, Webb and James (2015) explained that a teacher's mathematical knowledge necessitates reflection; and that reflection is pivotal to the construction of teacher knowledge. This study sought to determine how teachers' experiences of modelling and reflection on it filtered through to their resources, orientations or goals. A teacher's goals are largely underpinned by his/her orientations towards teaching and mathematics. A teacher will implement resources (intellectual, material and contextual resources (Schoenfeld 2011, 10) to reach these goals. Schoenfeld's theory of teacher decision-making was used to analyse the data. The three concepts allowed the author to make comparisons across the various modelling problems; and to explore the effect of modelling tasks on teacher thinking.

The important role of teachers reflecting on their own practice is confirmed in the literature (Beauchamp, 2015; Tzur, 2010, 59). Reflection in professional teacher development programmes therefore requires both a new experience and a focus on a teacher's own practice. Since reflection plays a significant role in any learning, the concept is diverse and many frameworks and levels of reflection exist in an attempt to clarify reflection on own practice. Reflection remains a personal, interpretative endeavour irrespective of the definition or framework. These frameworks and levels assist in developing a holistic view of reflection and in developing, extending and sharing reflection-specific vocabulary.

Many authors explain reflection in terms of levels (Hatton and Smith 1995; Jay and Johnson 2002 (in Korkko et al. 2016); Bean and Stevens 2002). Other authors suggest that reflection is not based on hierarchical aspects; all levels are necessary, integrated and important at different points in a teacher's reflection (Griffiths and Tann, 1992; Stanley, 1998). Arrastia, Rawls, Brinkerhoff and Roehrig (2013) identified what they called patterns in reflective thinking. The various lists or frameworks in this research are set out in terms of: a) time (when the reflection takes place) - Schön's (1987, 22) conceptions of reflection-on-action and reflection-in-action are relevant here; b) content (what the reflection is about); or c) effect (what the reflection changed in the practitioner's practice). Mason's $(2002,15)$ reflection-through-action resonates with the 
author, since it was anticipated that teacher reflection would impact on their practices. These three areas - time, content or effect -provide a broad structure for the multiple definitions or lists in literature.

Since modelling tasks were the vehicle of the professional development programme, they are briefly discussed.

\section{MODELLING AS A VEHICLE FOR MATHEMATICS TEACHER REFLECTION IN TEACHER DEVELOPMENT PROGRAMMES}

Modelling tasks are unstructured and they often contain many and varied data sources. Learning takes place through the process of constructing a model to explain, describe or make predictions based on a real life situation. Although model-eliciting activity research is focused on student learning, Schorr, Warner, Gearhart and Samuels (2007, 422) propose that 'parallel assumptions' about student learning must be applied to teacher learning in mathematics. Since students learn through meaningful problemsolving, so should teachers. Figure 1 provides an example of a modelling problem is given to assist the reader who is not familiar with this type of problem.

The task requires that students mathematise their understanding of distance and time in terms of the decimal numbers given. They have to understand what the numbers refer to in terms of length and time - a higher number for time in the air is better than having a higher number for distance from target. Modelling tasks are also designed for groups of students to solve, since learning is considered socially mediated and constructed. The teachers involved in the study were not familiar with this type of task.

Lesh and Doerr (2003b, 554-555) reiterated that a modelling perspective provides powerful constructs for how we understand and support the professional development of teachers. They further added that a modelling perspective assists in moving away from professional development that tells teachers what to do, but should be supporting teachers to see and interpret (which is largely reflective by nature) the complexities of teaching and learning. Doerr and Lesh $(2003,133)$ specified the overall goals of modeleliciting activities for teachers:

- $\quad$ To have teachers reveal their current ways of thinking.

- $\quad$ To test, revise and refine those ways of thinking.

- $\quad$ To share with colleagues for replication.

- $\quad$ To reuse their ways of thinking in multiple contexts.

Since Farmer, Gerretson and Lassak (2003) found that authentic learning tasks lead to better reflection in teachers; it may then hold that modelling tasks will result in growth in teacher reflection. Tan and Ang $(2013,373)$ used modelling problems and a blogbased reflection activity. They found that pre-service teachers were able to acquire 
A neighbouring school held its annual Paper Airplane Contest last week. Teams had to throw the plane from a starting point and aim to get it to a finish point marked on the school field. Each team was allowed three throws.

Problem: The judges have problems in deciding how to select a winner for this competition. They do nott know what to consider in determining who wins the award. The data and a description of how measurements were made have been included.

\begin{tabular}{|c|c|c|c|}
\hline \multicolumn{4}{|c|}{ Measurements } \\
\hline TEAM & $\begin{array}{l}\text { Amount of time in } \\
\text { air (seconds) }\end{array}$ & $\begin{array}{l}\text { Length of throw } \\
\text { (meters) }\end{array}$ & $\begin{array}{l}\text { Distance from } \\
\text { target (meters) }\end{array}$ \\
\hline \multirow[t]{3}{*}{ Team 1} & 3.1 & 11 & 1.8 \\
\hline & 0.1 & 1.5 & 8.7 \\
\hline & 2.7 & 7.6 & 4.5 \\
\hline \multirow[t]{3}{*}{ Team 2} & 3.8 & 10.9 & 1.7 \\
\hline & 4.2 & 13.1 & 5.4 \\
\hline & 1.7 & 3.4 & 8.1 \\
\hline \multirow[t]{3}{*}{ Team 3} & 4.2 & 12.6 & 4.5 \\
\hline & 5.1 & 14.9 & 6.7 \\
\hline & 3.7 & 11.3 & 3.9 \\
\hline \multirow[t]{3}{*}{ Team 4} & 2.3 & 7.3 & 3.25 \\
\hline & 2.7 & 9.1 & 4.9 \\
\hline & 0.2 & 1.6 & 9.1 \\
\hline \multirow[t]{3}{*}{ Team 5} & 4.9 & 7.9 & 2.8 \\
\hline & 2.5 & 10.8 & 1.7 \\
\hline & 5.1 & 12.8 & 5.7 \\
\hline \multirow[t]{3}{*}{ Team 6} & 0.2 & 1.8 & 8.8 \\
\hline & 2.4 & 10.1 & 4.6 \\
\hline & 4.7 & 10.3 & 5.4 \\
\hline
\end{tabular}

You will have to prepare a presentation for the judges of the contest. Explain a method that will assist them in choosing this years' winner. Your explanation must enable them to use your method in future competitions also.

Amount of time in air - means the number of seconds from the time of throw to landing. Length of throw - means straight line distance from the start point to the landing point.

Distance from target - means straight line distance from the landing point to the finish point.

Figure 1: Example of modelling a problem.

Image $\Theta$ credit: Lesh and Doerr (2003a, 7) with further data from https://engineering.purdue.edu/ENE/ Research/SGMM/CASESTUDIESKIDSWEB/index.htm. 
knowledge about modelling as a classroom activity. Jung and Brady (2016) found that from a models and modelling perspective, teachers' thinking about their students developed in a short time span. Their research, however, had a teacher specifically implement modelling tasks in her classroom. This study relied on the effect of reflection after teachers had experienced modelling tasks as problem- solvers themselves and then as observers of students/learners solving the problems. Caldeira's (2008) study found that mathematical modelling produced critical reflections in teachers' discussions on environmental education. It was, therefore, anticipated that mathematics teacher reflection would develop through a modelling perspective on professional development. In order for teachers to interpret their teaching activities differently, they need to develop reflective practices. Reflection should be considered a micro-competency of a modelling perspective on teacher development. Modelling tasks may create an environment where the symbiotic relationship between teacher resources, orientations, goals and reflection takes place. The questions this study sought to answer, from a qualitative perspective, were:

- What is the nature of mathematics teacher reflection when participating in a modelling-based teacher development programme?

- What changes in teacher resources, orientations and goals could be determined from their reflection during the programme?

\section{THE STUDY: PARTICIPANTS AND PROCEDURES}

The study involved five primary school mathematics teachers who took part voluntarily in a professional development programme for a period of one year. The schools where these teachers were teaching were selected based on a convenience sample. The study took place in South Africa at primary schools where teaching was predominantly traditional. This means that lessons followed a predictable script of teacher explanations followed by students practicing the set methods shown by the teacher.

Permission for the study was granted by the school principals and department of education. Ethical clearance for the study was given by the affiliated university. The study followed a qualitative design-research approach so it was structured around three phases. A planning and preparation phase, an experiment and a retrospective analysis (Bakker 2004, 3). The planning phase involved the literature review and instrument design. The experiment phase is "experimental but not an experiment" (Kelly 2006, 114 emphasis in original). The professional development programme is the experimental phase of design research. The researcher designs an innovative learning environment and studies the effects thereof. The comprehensive design concept of Fosnot, Dolk, Zolkhower, Hersch and Seignoret $(2006,7)$ was considered sound: 
...we engaged in-service teachers in experiences that involved action, reflection, and conversation within the context of learning/teaching. We took the perspective that teachers need to construct new gestalts, new visions of mathematics teaching and learning.

A retrospective analysis took place. The analysis involved scrutinising and coding teachers' written responses to qualitative open-ended questions.

The professional development sessions were adapted, reformulated or re-designed after the analysis had taken place. A new planning and preparation phase took place followed by a new phase of experimental intervention. Each phase was introduced with a new modelling problem. The modelling tasks used were the Airplane task (Lesh and Doerr 2003a, 7), Summer jobs (Lesh and Lehrer, 2000, 685) and Tangram Toys (Brousseau 1997, 177).

Teachers were not required to specifically teach modelling problems during the observed lessons in their classrooms but to follow the requirements of their curriculum and schools. The intervention programme followed three cycles over a 10 -week period. This was repeated for three different modelling tasks.

Table 1: Teacher intervention programme.

Classroom Observation. Researcher observed teacher in her own classroom. Teachers had completed an open-ended questionnaire before the lesson was observed and after the lesson. Researcher used the pedagogy scale, use of context scale and mathematical content scale for classroom observation. (Fosnot et al. 2006).

Session 1: Teachers worked on a modelling problem as a group with a follow up discussion. Teachers completed an open-ended reflection questionnaire based on the session.

Session 2: Teachers observed groups of students solving the same problem. Teachers answered an open-ended reflection questionnaire after observing students working on the modelling problem.

Session 3: Follow up discussion of didactisation principles and resources for teaching. Recording and transcripts of discussion.

This was repeated three times during the programme with a different modelling problem for each iteration of the programme.

Reflection was gauged at various intervals of the programme. Teachers completed an open-ended questionnaire at the beginning and end of the professional development programme and their responses were analysed and compared. Questions such as: What do you think makes a good mathematics teacher? How do you know if a mathematics lesson has gone well? How do you know if students have understood the lesson? were asked. Teachers also completed an open-ended questionnaire before the classroom observations (What is the goal of the lesson? What are you anticipating students will find difficult? Why is today's concept important for future understanding?). (Biccard, 2013) Teachers were also asked to reflect on the modelling sessions they experienced 
as a group and on their experiences when observing groups of students/learners solve the same modelling problem in the following session held two weeks later. This open-ended reflective questionnaire included questions such as: What mathematical concepts and understandings did this problem access? How important are these ideas? Could you treat these ideas equally well in a traditional way? The questionnaire the teachers answered after observing students solving modelling problems included questions such as: What stood out/surprised you/ impressed you and so forth These open-ended questionnaires can be considered as "reflection tools" that stimulate reflection (Hamilton, Lesh, Lester and Yoon 2007, 349). These authors argue for reflection to be more tacit or implicit in nature.

The five teachers are referred to as Mrs A, B, C, D and E. The teachers' pre and post lesson open-ended questionnaires were analysed, compared and interpreted for teachers' resources, orientations and goals. The teachers' own words are used in reporting on reflection in this study. These verbatim accounts enhance the credibility of the study.

\section{RESULTS AND DISCUSSION}

After being exposed to the first modelling problem the teachers had to solve as a group, they were sceptical and negative about the value of modelling tasks. Mrs B read the question and immediately responded: "This was not going to work." Later, in her reflection after the session, she wrote: "I think one has to experience this first before the penny drops. We underestimate the children at the best of times. Their confidence will also be boosted once they have solved a few problems themselves." (Biccard 2013, 190 emphasis added).

Once the teachers had observed groups of students/learners tackle the same problem, they were asked what they found "surprising". Their responses are part of the content of reflection.

Reflecting on the modelling task allowed the teachers to reveal their current ways of thinking. The responses highlighted the traditional orientations that teachers have about mathematics. The teachers were surprised about: student enthusiasm and interest in the task; student independence regarding understanding and interpretation; and student collaboration during group work. This may not be what teachers with a traditional mode of instruction usually experience; and they were surprised by how the task created a mathematical learning environment that is conducive to working mathematically without mimicking specific methods. The modelling task presented teachers with a different way of thinking about teaching, learning and tasks in mathematics classrooms. These results reaffirm Lesh and Doerr's (2003b) ideas of professional development that supports teachers in interpreting the complexities of mathematics classrooms rather than telling them what to do. Their individual reflective written responses after observing groups of students solve the first and third modelling tasks were analysed. 
Table 2: Teacher reflection on modelling task (Biccard 2013, 189)

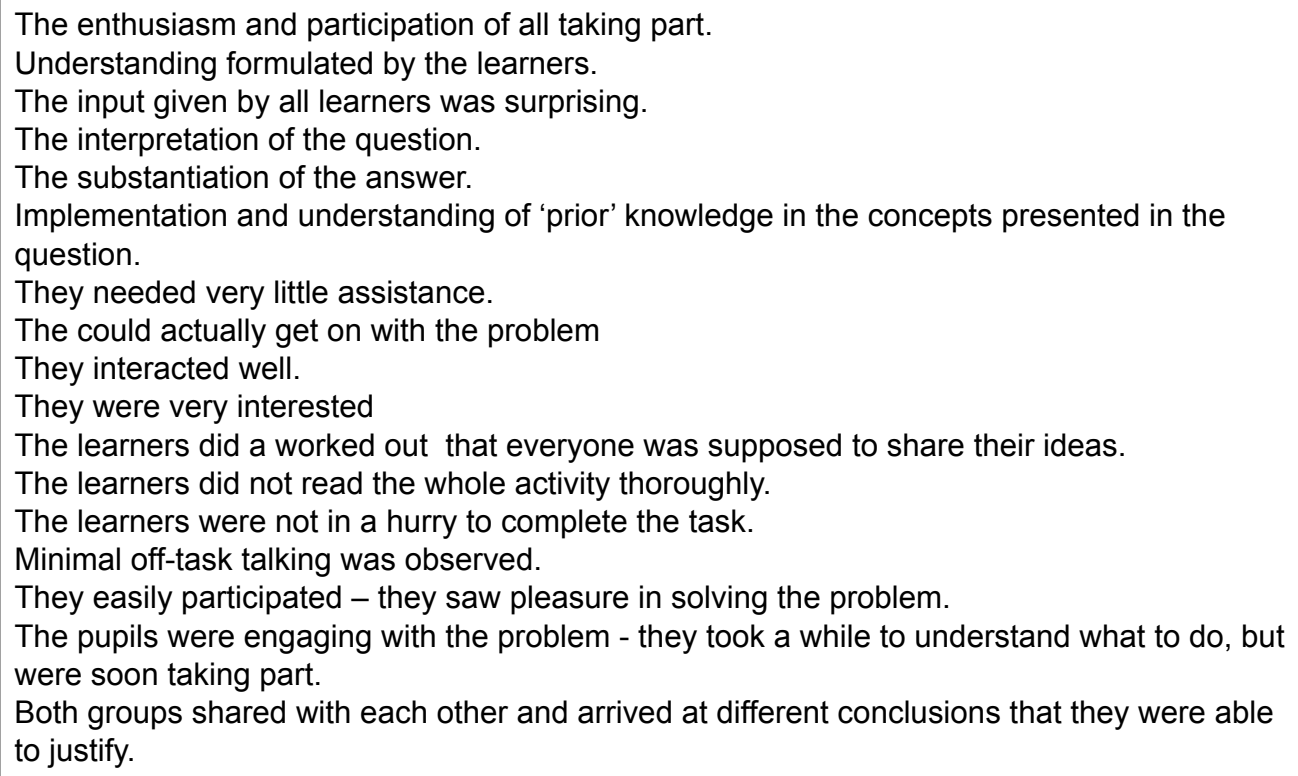

Mrs A's response after the first modelling task focused on how modelling could help students to better remember things: "They come to an understanding/conclusion which allows them freedom to reach a conclusion they understand which will stay with them, that they will remember for longer" while her reflection the following year showed that she was concerned about mathematical understanding: "Leaners formulate methods that make sense to them...it is easier to guide them to methods required which allows learners to truly understand the concept as a whole". At this stage she felt that with a focus on remembering methods "weak learners fall further behind if they have not grasped it. Her orientation had shifted from mathematics as remembering methods to mathematics as understanding concepts.

Mrs B's first reflection was about learners getting mathematics 'right': "They realized that the smallest value would be the number for the third column" while after the last task she wrote about how learners actually build and develop ideas: "They develop their thinking by discussing problems. Listening to others and building ideas. Weaker learners can also share their ideas and the discussion can help them structure their own thoughts".

Mrs C, presented her thoughts about the limitations of group work in the reflection of the first task: "some learners cannot work in groups" while after the final task she mentioned that problem-solving of this nature would assist weak learners as they "might have a chance to have some input".

In her first session reflection, Mrs D wrote about learners' prior knowledge. She felt that it was not an inhibitive factor in modelling; while in her later reflections she 
consolidated this idea by indicating that modelling problems could be employed to introduce a concept (a traditionally held belief is that problem-solving is best left for when the 'basics' are covered) since it "clarifies conceptual ideas and creates contextual awareness" which shows a refining of her earlier reflection about prior knowledge of students.

Mrs E's initial reflection portrayed modelling as "time consuming which does not allow for adequate content coverage" while in her final reflection she felt that traditional teaching relied on remembering methods and not on reasoning and thinking. All five teachers were concerned about time constraints in terms of their responsibility to cover the curriculum. These responses show a possible shift in teacher resources and orientations. Teacher knowledge may now incorporate an understanding of the value of modelling tasks for learners of all ability levels while traditional teaching is seen as a memory-laden approach. Teachers were also developing an appreciation for the advantages of group work for mathematical understanding.

At the end of the last classroom observation, the teachers were asked to comment on what they thought was different about themselves or their teaching during the last lesson compared to the first lesson observation. This time teachers were reflecting on their own practice through the development programme. The development of teacher orientations and goals is evident in their responses while the effect of reflection may be gauged here. Tzur's (2001) finding that reflection allows teachers a deeper view of how they can foster mathematics learning is evident here (Biccard 2013, 279):

Mrs A: Learners interacted more with one another than they did in the first lesson.

Mrs B: I facilitated and the children were in control.

Mrs C: In the first lesson I did a lot of talking. In the last lesson I only read through the task, the learners had to find the mistake with no help given.

Mrs D: I was the centre of teaching, now I try to facilitate learning

Mrs E: I continue to think about what I'm doing in the class as concepts/material must be covered, however it is easier to 'do' the work and 'tell' them how to - it's a challenge not to keep falling into this method. I try to allow the children to talk and do more in the lesson.

Teachers' orientations now focused on students and student learning and not on their own actions in the lesson. Mathematical learning is seen more in terms of students' activity than in terms of teacher actions. Teacher resources included facilitation as a teaching approach. The teachers' orientations (learners can learn by facilitation) and goals (learner-centred lessons) informed the adoption of this approach. The sentiments of Ticha and Hospesova (2006), that reflection should lead to improvements in classroom culture is evident.

Teachers were asked to set out the goals of their observed lessons during the programme. 
Table 3: $\quad$ Change in teacher goals (Biccard 2013, 279)

\begin{tabular}{|l|l|l|l|}
\hline Teacher & $\begin{array}{l}\text { Goal for baseline } \\
\text { lesson }\end{array}$ & Goal for final lesson & Changes in goals \\
\hline A & $\begin{array}{l}\text { With a discount you need } \\
\text { to do a subtraction. }\end{array}$ & $\begin{array}{l}\text { Ordering decimal } \\
\text { numbers, showing their } \\
\text { answers while explaining } \\
\text { what they were doing. }\end{array}$ & $\begin{array}{l}\text { More focus on student } \\
\text { activity. }\end{array}$ \\
\hline B & $\begin{array}{l}\text { Have a clear } \\
\text { understanding of } \\
\text { perimeter and area; and } \\
\text { the difference between } \\
\text { the two concepts. }\end{array}$ & $\begin{array}{l}\text { That they would know } \\
\text { where to start in solving } \\
\text { the problem, order their } \\
\text { working and find the } \\
\text { solution. }\end{array}$ & $\begin{array}{l}\text { A problem-solving } \\
\text { orientation. }\end{array}$ \\
\hline C & $\begin{array}{l}\text { Write a decimal number } \\
\text { or common fraction as a } \\
\text { percentage. }\end{array}$ & $\begin{array}{l}\text { To order numbers } \\
\text { (decimals) by solving the } \\
\text { problem. }\end{array}$ & $\begin{array}{l}\text { Introduced a modelling } \\
\text { problem to learn through. }\end{array}$ \\
\hline D & $\begin{array}{l}\text { That they would not get } \\
\text { worried when they get a } \\
\text { BODMAS sum. }\end{array}$ & $\begin{array}{l}\text { The mathematical } \\
\text { reasoning necessary to } \\
\text { solve word problems. }\end{array}$ & $\begin{array}{l}\text { Content to concept } \\
\text { change. }\end{array}$ \\
\hline E & $\begin{array}{l}\text { A solid knowledge of } \\
\text { the basic tables and the } \\
\text { extended tables (up to } \\
\text { 120 x 900) are essential } \\
\text { in order to multiply large } \\
\text { numbers accurately. }\end{array}$ & $\begin{array}{l}\text { That 3D shapes are } \\
\text { made up of 2D shapes - } \\
\text { that cubes are similar to } \\
\text { squares. }\end{array}$ & $\begin{array}{l}\text { Content to concept } \\
\text { change. }\end{array}$ \\
\hline
\end{tabular}

Their lesson goals at the end of the programme reveal a focus on more independent work for their students; or a shift from a content orientation to a concept orientation. The effect of reflection is also gauged here. The goals for the final lesson displayed a more global view of mathematical learning than the atomised lists for the baseline lessons. Teacher goals were more focused on their own pedagogy and not only on curriculum goals.

Teachers were also asked to consider the question: "What do you think makes a good mathematics teacher?" Their responses were taken at the beginning and end of the programme. 
Table 4: What makes good mathematics teacher responses (Biccard 2013, 280)

\begin{tabular}{|c|c|c|c|}
\hline Teacher & Baseline Questionnaire & Post Questionnaire & Change in orientation \\
\hline$A$ & $\begin{array}{l}\text { In-depth understanding } \\
\text { of the subject. }\end{array}$ & $\begin{array}{l}\text { Someone who } \\
\text { understands the } \\
\text { subject inside and } \\
\text { out and can convey } \\
\text { that understanding in } \\
\text { numerous ways to reach } \\
\text { those taught. }\end{array}$ & $\begin{array}{l}\text { Included the value of } \\
\text { varying representations. } \\
\text { Change in goals - } \\
\text { increase knowledge of } \\
\text { representations. }\end{array}$ \\
\hline B & $\begin{array}{l}\text { You have to have a very } \\
\text { sound understanding of } \\
\text { the content in order to } \\
\text { dissect it for children. }\end{array}$ & $\begin{array}{l}\text { Dedication, creating } \\
\text { mental pictures for } \\
\text { children, routine and } \\
\text { passion for the subject. }\end{array}$ & $\begin{array}{l}\text { More holistic and } \\
\text { student-centered. }\end{array}$ \\
\hline $\mathrm{C}$ & $\begin{array}{l}\text { Knowledge of subject } \\
\text { matter, experience, } \\
\text { dedication and } \\
\text { understanding how } \\
\text { children learn. }\end{array}$ & $\begin{array}{l}\text { Make the subject } \\
\text { interesting - introduce } \\
\text { different methods. } \\
\text { Build confidence in } \\
\text { learners' skills and } \\
\text { abilities. } \\
\text { Identify when a concept } \\
\text { is not working and be } \\
\text { able to change the } \\
\text { lesson. }\end{array}$ & $\begin{array}{l}\text { More student-centered } \\
\text { and more reflective. } \\
\text { Change in goals - varied } \\
\text { representations. }\end{array}$ \\
\hline $\mathrm{D}$ & $\begin{array}{l}\text { Time, effort, experience, } \\
\text { subject knowledge and } \\
\text { passion. }\end{array}$ & $\begin{array}{l}\text { One who is prepared, } \\
\text { knowledgeable and has } \\
\text { a teachable spirit. One } \\
\text { that welcomes his or her } \\
\text { mistakes and always } \\
\text { considers learning as the } \\
\text { most important concept. }\end{array}$ & $\begin{array}{l}\text { Holistic reflection. } \\
\text { Change in goals - a } \\
\text { focus on learning. }\end{array}$ \\
\hline$E$ & $\begin{array}{l}\text { Positive attitude and } \\
\text { willingness and desire to } \\
\text { learn. }\end{array}$ & $\begin{array}{l}\text { Enjoyment of the subject, } \\
\text { willingness to try new } \\
\text { ways of doing things - } \\
\text { flexibility, understanding } \\
\text { of key concepts. }\end{array}$ & $\begin{array}{l}\text { Focus on teacher } \\
\text { flexibility. } \\
\text { Change in goals - to try } \\
\text { new ideas. }\end{array}$ \\
\hline
\end{tabular}

Their responses were varied, with changes to their orientations and goals. Overall their responses in the baseline questionnaire showed a focus on the subject knowledge and content of mathematics, while their responses in the post programme questionnaire showed greater focus on conceptual understanding in mathematics. Their final responses were longer with teachers elaborating and reflecting more than their responses in the first questionnaire. The complexities of teaching are considered in the latter responses and teachers refined and revised their orientations and goals. The teachers considered 
their role in student learning acutely and realised that teaching is more than simply knowing and presenting content.

\section{CONCLUSION}

This article considered the nature and development of mathematics teacher reflection through professional development from a modelling perspective. Teacher reflection is an important aspect of a professional development programme. Teacher development can be supported through reflective platforms, such as mathematical modelling tasks. This enabled teachers to see and interpret aspects of their own teaching differently. Furthermore, it enabled the teachers and researcher to consider more tacit domains, such as orientations and goals. Reflection should be systematically integrated into the other activities of teachers. The teachers, however, need to consider reflection as an important aspect of their own learning. Reflection does not only lead to changes in teacher actions, but can also result in changes to more challenging areas, such as teacher orientations and teacher goals. This study adds insight into the potential of modelling for teacher development.

The study was limited to five primary school mathematics teachers in one particular city of South Africa. Since the teachers volunteered for the professional development programme, they may be more open and receptive to new experiences and reflection. This may not be the case with all teachers. However, building reflection into professional development programmes is considered important enough to suggest that it receives attention across all professional development domains. The role of modelling, as a springboard for advancing and revising teacher thinking around teaching and learning of mathematics, is also a field requiring further study. In trying to understand what teachers think about the nature of mathematics and their role in the classrooms, modelling tasks present teachers with a window to reflect on their own pedagogy. Furthermore, reflection tools (Hamilton et al. 2007, 350) that catalyse mathematics teacher reflection need to be constantly revised and refined. Reflective activities that support teacher change may have an impact on the way in which students learn. If students learn mathematics in a different way, it may break the cycle of negative orientation towards mathematics. Further research on the nature of teacher reflection when teachers implement modelling tasks in their own classrooms will also be valuable.

\section{REFERENCES}

Arrastia, M., E.S. Rawls, E.H. Brinkerhoff., and A.D. Roehrig. 2013. "The Nature of Elementary Preservice Teachers' Reflection during an Early Field Experience.” Reflective Practice 15 (4): 427- 444.

Artzt, A., E. Armour-Thomas, F.R. Curcio., and T.J. Gurl, T.J. 2015. Becoming a Reflective Mathematics Teacher. New York: Routledge. 
Bakker, A. 2004. Design Research in Statistics Education. Utrecht, CD- $\beta$ Press, Center for Science and Mathematics Education.

Bansilal, S., L. Webb., and A. James. 2015. "Teacher Training for Mathematical Literacy: A Case Study Taking the Past into the Future." South African Journal of Education 35 (1): 1-10.

Bean, T., and L.P. Stevens. 2002. "Scaffolding Reflection for Preservice and Inservice teachers." Reflective Practice 3 (2): 205-218.

Beauchamp, C. 2015. "Reflection in Teacher Education: Issues Emerging from a Review of Current Literature." Reflective Practice 16 (1): 123-141.

Biccard, P. 2013. "The Development of Didactisation Practices in Primary School Mathematics Teachers Through Modelling." PhD thesis, University of Stellenbosch.

Brady, C., R. Lesh., and S. Sevis. 2015. "Extending the Reach of the Models and Modelling Perspective: A Course-sized Research Site." In Mathematical Modelling in Education Research and Practice International Perspectives on the Teaching and Learning of Mathematical Modelling, edited by G. Stillman, W. Blum and M. Biembengut, 55-66. Switzerland: Springer

Brousseau, G. 1997. Theory of Didactical Situations in Mathematics. Didactique des Mathematiques, 1970-1990. Dordrecht, Netherlands: Kluwer Academic Publishers.

Caldeira, A.D. 2008. "Mathematical Modeling and Environmental education." Paper presented at the International Congress of Mathematics Education (ICME 11). TSG21: Mathematical Applications and Modeling in the Teaching and Learning of Mathematics. http://sg.icme11.org/document/get/493. (accessed May 31, 2017).

Dewey, J. 1910. How We Think. Boston: D.C. Heath \& Co. Publishers.

Doerr, H., and R. Lesh. 2003. A Modelling Perspective on Teacher Development. In Beyond Constructivism: Models and Modelling Perspectives on Mathematics Problem Solving, Learning, and Teaching, edited by R. Lesh and H.M. Doerr, 125-139. Mahwah, New Jersey: Lawrence Erlbaum Associates Publisher.

Farmer, J. D., H. Gerretson., and M. Lassak. 2003 What Teachers Take from Professional Development: Cases and Implications. Journal of Mathematics Teacher Education 6 (4): 331-360.

Fosnot, D.T., M. Dolk., B. Zolkower, S. Hersch, S., and H. Seignoret. 2006. "Mathematics in the City: Measuring Teacher Change in Facilitating Mathematization." Paper used at the coaching institute for numeracy and literacy leaders.

Griffiths, M., and S. Tann. 1992. "Using reflective practice to link personal and public theories." Journal of Education for Teaching 18 (1): 69-84. doi:10.1080/0260747920180107

Hamilton, E., R. Lesh, F. Lester., and C. Yoon. 2007. "The Use of Reflection Tools to Build Personal Models of Problem-solving." In Foundations for the Future in Mathematics Education, edited by. R. Lesh, E.Hamilton and J. Kaput, 349-366. Mahwah, New Jersey: Lawrence Erlbaum Associates Publishers.

Hatton, N., and D. Smith.1995. Reflection in Teacher Education: Towards Definition and Implementation. Teaching and Teacher Education 11 (1): 33-49. 
Jung, H., and C. Brady. 2016. Roles of a Teacher and Researcher During In Situ Professional Development around the Implementation of Mathematical Modeling Tasks. Journal of Mathematics Teacher Education no. 19: 277. doi:10.1007/s10857-015-9335-6

Kelly, A.E. 2006. “Quality Criteria for Design Research.” In Educational Design Research, edited by J. van den Akker, K. Gravemeijer, S. McKenney and N. Nieveen, 107-118. New York: Routledge.

Korkko, M., O. Kyro-Ammala., and T. Turunen.. 2016. "Professional Development through Reflection in Teacher Education." Teaching and Teacher Education 55: 198-206.

Lesh, R., and H. Doerr. 2003a. "Foundations of Models and Modelling Perspective." In Beyond Constructivism: Models and Modelling Perspectives on Mathematics Problem Solving, Learning, and Teaching, edited by. R. Lesh and H. M. Doerr, 333. Mahwah, New Jersey: Lawrence Erlbaum Associates Publisher.

Lesh, R., and H. Doerr. 2003b. "In What Ways does a Models and Modeling Perspective Move Beyond Constructivism?" In Beyond Constructivism: Models and Modelling Perspectives on Mathematics Problem Solving, Learning, and Teaching, edited by R. Lesh and H.M. Doerr, 519-556. Mahwah, New Jersey: Lawrence Erlbaum Associates Publisher.

Lesh, R., and R. Lehrer. 2000. "Iterative Refinement Cycles for VideotapeAanalyses of Conceptual Change." In Handbook of Research Design in Mathematics and Science Education, edited by A. Kelly and R. Lesh, 591-646. Mahwah, New Jersey: Lawrence Erlbaum Associates.

Llinares, S., and K. Krainer. 2006. "Mathematics (student) teachers and teacher educators as learners." In Handbook of Research on the Psychology of Mathematics Education: Past, Present and Future, edited by. A. Guiterrez and P. Boero, 429-459. Rotterdam, Netherlands: Sense Publishers.

Maaß, K., and J. Gurlitt. 2011. LEMA - "Professional Development of Teaching in Relation to Mathematics Modelling." In Trends in the Teaching and Learning of Mathematical Modelling - Proceedings of ICTMA 14, edited by G. Kaiser, W.Blum, R. Borromeo Ferri and G. Sillman, 629-639. New York: Springer.

Mason, J. 2002. Researching Your Own Practice: the Discipline of Noticing. Taylor and Francis e-library.

Posthuma, A.B. 2012. "Mathematics Teachers' Reflective Practice within the Context of Adapted Lesson Study". Pythagoras 33 (3): 1-9. doi: 10.4102/pythagoras.v33i3.140.

Russell, T. 2005. “Can Reflective Practice be taught?” Reflective Practice 6 (2): 199-204.

Schoenfeld, A.H. 2011. How We Think: A Theory of Goal-orientated Decision Making and its EducationalAapplications. New York: Routledge.

Schön, D. 1987. Educating the Reflective Practitioner. San Francisco: Jossey-Bass Inc. Publishers.

Schorr, R.Y., L. Warner, D. Gearhart., and M. Samuels. 2007." Teacher Development in a Large Urban District and the Impact on Students." ,In Foundations for the Future in Mathematics Education, edited by R. Lesh, E. Hamilton and J. Kaput, 431-447. Mahwah, New Jersey: Lawrence Erlbaum Associates Publishers.

Stanley, C. 1998. “A Framework for Teacher Reflectivity.” TESOL Quarterly 32 (3): 584-591. 
Stein, M., and M.S. Smith. 1998. "Mathematical Tasks as a Framework for Reflection: from Research to Practice." Mathematics Teaching in the Middle School 3 (4): 268-275.

Tan, L.S., and K.C. Ang. 2013. "Pre-service Secondary School Teacher's Knowledge in Mathematical Modelling - A Case Study." In Teaching Mathematical Modelling: Connecting to Research and Practice, edited by G. A. Stillman, G. Kaiser, W. Blum and J. P.Brown, 373-383. Dortrecht: Springer.

Ticha, M., and A. Hospesova. 2006. "Qualified Pedagogical Reflection as a Way to Improve Mathematics Education.” Journal of Mathematics Teacher Education 9: 129-156.

Tzur, R. 2001. "Becoming a Mathematics Teacher-educator: Conceptualizing the Terrain through Selfreflective Analysis." Journal of Mathematics Teacher Education 4 (4): 259-283.

Tzur, R. 2010. "How and What might Teachers Learn through Teaching Mathematics: Contributions to Closing an Unspoken Gap." In Learning Through Teaching Mathematics, Mathematics Teacher Education, edited by R. Leikin and R. Zazkis, 49-67. Dordrecht: Springer.

Zaslavsky, O., and R. Leiken. 2004. "Professional Development of Mathematics Teacher Educators: Growth through Practice." Journal of Mathematics Teacher Education 7: 5-32.

Zeichner, K., and D.P. Liston. 1996. Reflective Teaching: An introduction. Mahwah, New Jersey: Lawrence Erlbaum Associates. 